\title{
Social Demographic Factors That Influence Transformational Leadership Styles among Top Management in Selected Organizations in Malaysia
}

\author{
Kabeer Abdullahi Mohammed ${ }^{1}$, Jamilah Othman ${ }^{1} \&$ Jeffrey Lawrence D'Silva ${ }^{1}$ \\ ${ }^{1}$ Laboratory of Citizenship \& Leadership, Institute for Social Science Studies, Universiti Putra Malaysia, \\ Selangor, Malaysia \\ Correspondence: Kabeer Abdullahi Mohammed, Laboratory of Citizenship \& Leadership, Institute for Social \\ Science Studies, Universiti Putra Malaysia, Putra Infoport, 43400 UPM Serdang, Selangor, Malaysia. Tel: \\ 60-1-644-9818. E-mail: abdullahimohammed35@yahoo.com
}

Received: June 5, 2012 Accepted: July 7, 2012 Online Published: October 18, 2012

doi:10.5539/ass.v8n13p51 URL: http://dx.doi.org/10.5539/ass.v8n13p51

\begin{abstract}
Literatures have not adequately discusses the influence of demographic variables on Leadership styles among top management in Malaysian organizations. Hence, the overall aim of the study was to investigate if there is significant difference between social demographic factors and transformational leadership style among top management in selected organizations in Malaysia. Data was collected through an instrument of leadership styles known as the MLQ to test the dependent variable (Transformational leadership). The independent variables in this study comprises of gender, race, marital status and educational level. The result of the independent samples t-test and ANOVA revealed that there is no significant difference between social demographic factors and transformational leadership styles. The study concludes that transformational leadership styles do not depends on social demographic factors.
\end{abstract}

Keywords: Malaysia, social demographic factors, leadership styles

\section{Introduction}

There seem to be unending research on what constitute effective leadership behavior among top management in contemporary organizations. Over the years, researchers have developed models, theories and assumptions all in an attempt to explain effective leadership in organizations. For example, Path-goal theory by House and Mitchell (1974), life-cycle theory developed by Hersey and Blanchard (1969), Leader-Member Exchange theory (LMX) by House, Fielder (1967) contingency theory, Burns (1978) Transformational leadership and a host of other theories all attempted at one point in time to provide detailed explanation on what constitute leadership. Leadership is a popular concept that has been used in many different ways. Jamilah et al (2012) argued that, even in everyday usage the term leadership is somehow ambiguous. It is used to refer to the holders of certain formally defined positions in an organizational settings, as when speaking of the party leadership' or the union leadership. But is also used to denote a particular type of behavior; when someone is commended for displaying outstanding leadership' it is their actions that are being praised. Such a person may or may not occupy a position of leadership.

The current study concentrate on the new trend of leadership that emerged in the 1990s as organizations began to undergo major structural changes due to diversified workforce, work-family conflict and perhaps the recent phenomenon of increase in knowledgeable workforce. The result of these changes has made researchers to focus their attention on transformational leadership in order to explain the factors that are critical to effective leadership behavior in organizations. In this regard, Burns (1978), Bass (1985), Bass and Avolio (1995) among others developed a framework that conceptualized transformational leadership. According Burns (1978) transformational leadership is a process of positive influence through which leaders motivate their followers to achieve organizational objectives beyond what is originally stated. Furthermore, Burns (1978) argued that transformational leaders inspire followers by aligning their own and followers value system with important moral principle. Based on these scenarios a lot of researches have been carried out on transformational leadership in organizational settings (Jamilah et al 2012; Weichun et al 2011; Bass and Avolio 1995) The result 
of these studies has identified effective transformational leadership style depends on how employee's perceived their leader in terms of goals settings and motivating them to achieve those goals (Jamilah et al 2012; Beamish, et al. 1999; Truckenbrodt 2000; Sarros and Santora 2001 Asgari et al 2009).

However, besides the already established factors that influence transformational leadership styles by Burns (1978), social demographic factors also have a major role in determining leadership behavior in organizations. It is important to study these factors given their importance to organizational success. In this regard, Stelter (2002) argued that more women are now entering labor force and this trend is accompanied by unprecedented increase in ethnic minorities especially in the developing countries. The implication of this development to organizational leadership is enormous, first, the differences in social demographic factors is a great advantage to organization if properly harnessed. Second, organizations need to know what constitute effective leadership as it relates to social demographic variables.

\subsection{Social Demographic Factors That Influence Leadership Styles}

Social demographic factors in this research comprises of gender, race, marital status and level of educational. Previous researches on the influence of social demographic factors have study the phenomenon from different perspectives, however this study will provide detailed explanation on the nature of these differences and the impact it has on organizations. Therefore, in this study one of the social demographic factors is gender. While research on Gender refers to social-psychological categories of masculinity (male related characteristics) and femininity (female related characteristics) Previous research on gender as it relate to organizational leadership has revealed that the main reason why women are underrepresented in organizational top management position has to with specialties in gender roles (Larocca, 2003). Research conducted over the years has revealed that women are generally expected to endorse the idea of affirmative action than their male counterpart (Eddy, 2008; Harrison et al 2006)

In their comparative study between women and men leaders in rural Nigeria, Deji and Makinde (2006) have found that women leaders had a higher level of external orientation and leadership skill than men. However the goal of transformational leaders is to set high standard of moral by promoting ethical policies and procedures which help followers establish a basis for moral and action (Avolio, 1995) Gibson (1995) found male leaders to display more transformational leadership behavior than their female counterpart in terms of goal settings. In addition to gender, another variable in this study is race. Race in this study refers to distinctive characteristic used to distinguish between groups of people. These basic features which differentiate races include color of skin, color of hair, language and facial features. Organizations are now diverse comprising of people from different racial background, ethnicity and culture. The importance of understanding the role race plays in organizational leadership is paramount given the nature of workplace in contemporary world which is diversified. Despite the abundant literatures on race-ethnicity especially in organizational leadership, understanding the connections have been $\mathrm{s}$ difficult tasks to researchers mostly because of the dynamic nature of race which require different study and methodology. In this regard literature on race has used methodology from sociological perspective mainly looking at the issue as it relate to discrimination and stereotyping (Ospina and Foldy 2009, Alba 1990, Nancy and Robert 1996). According to Eddy (2008) the complex natures through which diverse organizations operate nowadays require a practical solution hence the need for diversity management due to composition of many races working together. As such, diversity management include a range of policies adopted by organization such as diversity policy statement, active recruitment, training and development which are all consider to be effective in managing diverse employees (Eddy, 2008)

Besides this, evidence from the literature that marital status of an individual might influence his or her leadership style is also a bit contradictory. In fact there is no sufficient research to support the assumption whether single or married individuals are perceive to display appropriate leadership styles in organizations. However, there is a unanimous agreement that the goal of transformational leadership is to influence followers to achieve organizational objective through change of behavior therefore the issue of marital status is of little significance. Consequently, Leadership is about developing people, leaders share their responsibility and authority with others (Russell, 2001). Furthermore, educational qualification is another social demographic factor in this study, however there is no sufficient research also to justify that leadership styles might be influence by educational qualification. In other words, the employees can argue, make decision and give their opinions as a contribution to the organization without estimating their level of education. Therefore, educational qualification is more relevant in terms of goals accomplishment that required more expertise.

Hence, the aim of this study is to determine if transformational leadership styles varies according to social demographic factors. 


\section{Methodology}

This study used survey research methodology where data was gathered through the use of questionnaires from the sample selected to represent a larger population. The research employed a self-report instrument, Multifactor Leadership Questionnaire (MLQ) developed by Bass and Avolio (1995) to measure the dependent variables (leadership styles). The demographic information part of the questionnaire basically required respondent to state their gender, marital status, educational level and race in order to assess the independent variables (social demographic factors). In terms of reliability tests for the instruments used in this research, a total of 30 employees from a public agency in Malaysia were requested to participate in the pre testing of the instrument. The result of the reliability test indicated a high cronbanch alpha for the entire construct which ranges between .85 to .90 exceeding Nunannaly (1978) recommended threshold. In terms of validity of the instruments the MLQ was validated from previous researches, and a number of expert have agreed on its internal consistency before administering it on the respondent (Sarror and Santora, 2001, Brown, 2003, Judey, 2010). The population in this study consists of administrative employees and their supervisors in selected public and private organizations in Malaysia. The research utilized Simple random sampling techniques; the selection of sample size was based on formula by krejcie and Mogan (1970).

The respondents were assured confidentiality and were given adequate time answer the questionnaires without any interruption in order to avoid any leading influence and disruption on their work. The data collection processes lasted for a period of twenty working days. In order to ensure adequate response two follow-ups were made to the organizations. At the end of the exercise out of the initial five hundred (500) questionnaires distributed only three hundred and seventy-nine (379) were appropriately filled and returned to the researchers. All items in the questionnaire were based on five-point likert type except on demographic part which required respondent to choose one answer that appropriately describes them.

\section{Data Analysis}

The data were analyzed using latest SPSS statistical software. ANOVA, independent sample t-test was carried out to see if there is any statistical difference between and among the groups. The Levene's test for equality of variances was performed to test whether the variance of scores for the two groups (leadership styles and social demographic factors) is similar.

\section{Result}

The following are the results of this study, showing frequencies and percentage of gender, race, marital status and educational qualifications. 
Table 1. Social demographic profile of the respondents

\begin{tabular}{lll}
\hline Variables & Frequency & Percent \\
\hline GENDER & 240 & 63.3 \\
Male & 139 & 36.7 \\
Female & & \\
RACE & 300 & 79.2 \\
Malay & 51 & 13.5 \\
Chinese & 25 & 6.6 \\
Indians & 3 & .3 \\
Others & & \\
MARITAL STATUS & 31 & 8.2 \\
Single & 324 & 85.5 \\
Married & 19 & 5.0 \\
Divorce & 5 & 1.3 \\
Widow/widower & & \\
EDUCATIONAL QUALIFICATION & 1 & .3 \\
SPM/MCE & 1 & .3 \\
STPM/HSC & 4 & 1.1 \\
Diploma & 107 & 28.2 \\
Bachelor & 218 & 57.5 \\
Masters & 28 & 12.7 \\
PhD & & \\
\hline 4.1 Gender and Leadership Syles & \\
\hline
\end{tabular}

4.1 Gender and Leadership Styles

The result of t-test indicated there was a significant difference between the two groups and the mean for: (Male: $\mathrm{M}=3.9378, \mathrm{SD}=50527$ ) and (female: $\mathrm{M}=3.8752, \mathrm{SD}=517663$ ).

Table 2. Gender and leadership styles t-test

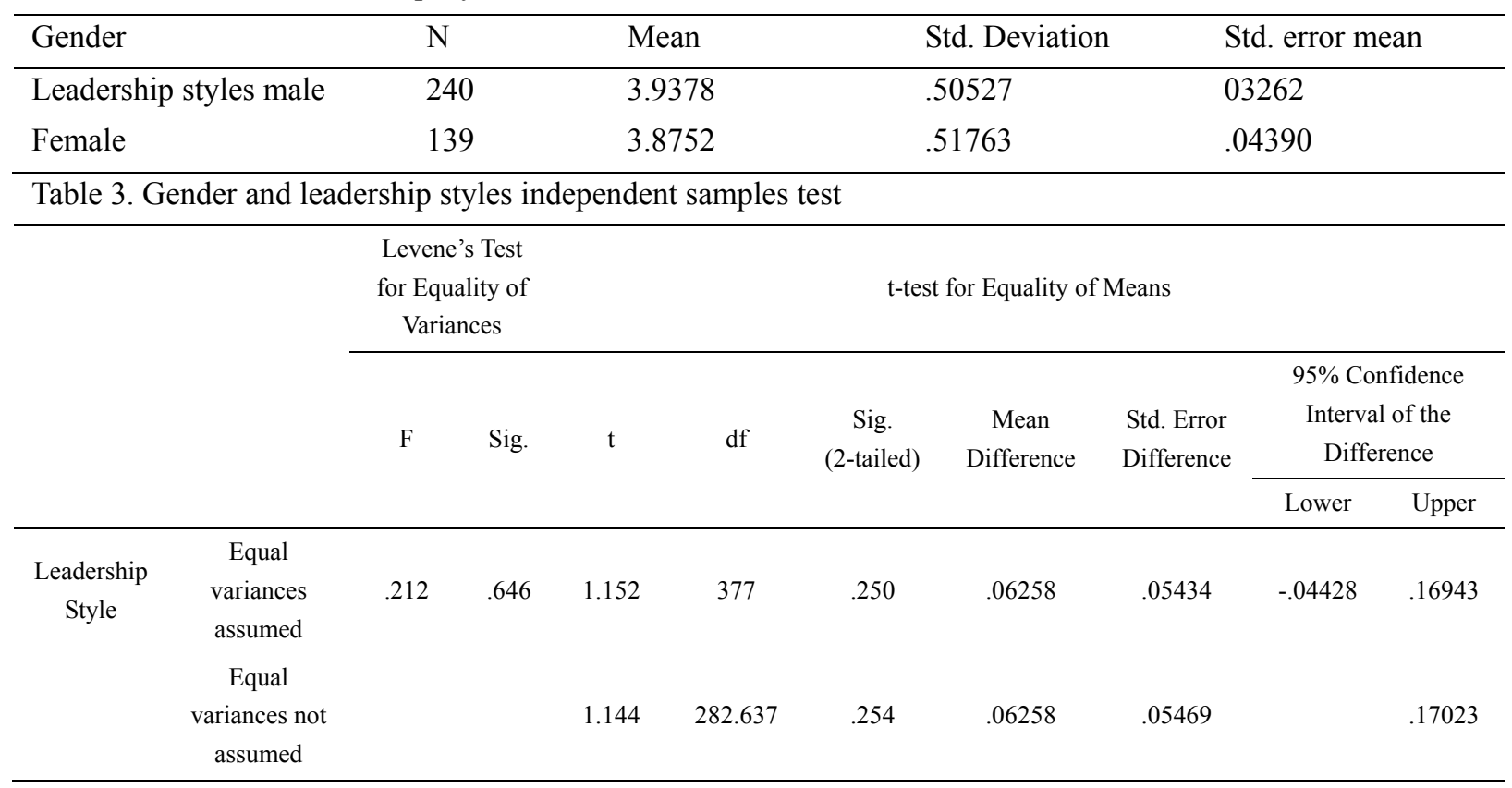




\subsection{Race and Leadership Styles}

Since race was categorized into more than one group, one way analysis of variance was carried out. The result is presented below. From the ANOVA table below since the sig. Value is 0.30 this value is less than 0.5 therefore we conclude that the four condition of (Malay, Chinese Indians and others) are statistically different.

Table 4. Race and leadership ANOVA

\begin{tabular}{llllll}
\hline Leadership styles & Sum of squares & Df & Mean square & F & Sig \\
\hline Between Groups & 2.315 & 3 & .772 & 3.013 & .030 \\
Within Groups & 96.023 & 375 & .256 & & \\
Total & 98.337 & 378 & & & \\
\hline
\end{tabular}

Table 5. Multiple comparisons race

Dependent Variable: Leadership Style

Tukey HSD

\begin{tabular}{lllllll}
\hline (I) a3: (Race: ) & (J) a3 (Race: ) & Mean Difference (I-J) & Std. Error & \multicolumn{2}{l}{ Sig. } & \multicolumn{2}{l}{ 95\% Confidence Interval } \\
\multirow{2}{*}{ Malay } & & & & & Lower Bound & Upper Bound \\
& Chinese & -.21893 & .07664 & .023 & -.4167 & -.0211 \\
& Indian & -.11751 & .10534 & .680 & -.3893 & .1543 \\
\multirow{4}{*}{ Chinese } & Others race & -.17225 & .29361 & .936 & -.9299 & .5854 \\
& Malay & .21893 & .07664 & .023 & .0211 & .4167 \\
& Indian & .10142 & .12354 & .845 & -.2174 & .4202 \\
\multirow{3}{*}{ Indian } & Others race & .04667 & .30062 & .999 & -.7291 & .8225 \\
& Malay & .11751 & .10534 & .680 & -.1543 & .3893 \\
& Chinese & -.10142 & .12354 & .845 & -.4202 & .2174 \\
\multirow{3}{*}{ Others race } & Others race & -.05475 & .30919 & .998 & -.8526 & .7431 \\
& Malay & .17225 & .29361 & .936 & -.5854 & .9299 \\
& Chinese & -.04667 & .30062 & .999 & -.8225 & .7291 \\
& Others race & .05475 & .30919 & .998 & -.7431 & .8526 \\
\hline
\end{tabular}

*. The mean difference is significant at the 0.05 level.

4.3 Marital Status and Leadership Styles

To determine if the means for marital status is statistically significant one way ANOVA was carried out to compare the means between the groups. From the result below sig. value .076 value is greater than 0.5

Table 6. Marital status and leadership ANOVA

\begin{tabular}{llllll}
\hline Leadership styles & Sum of squares & Df & Mean square & F & Sig \\
\hline Between Groups & 1.782 & 3 & .594 & 2.307 & .076 \\
Within Groups & 96.555 & 375 & .257 & & \\
Total & 98.337 & 378 & & & \\
\hline
\end{tabular}


Table 7. Multiple comparisons marital status

\begin{tabular}{|c|c|c|c|c|c|c|c|}
\hline \multicolumn{7}{|c|}{ Dependent Variable: Leadership Style } & \\
\hline \multirow{2}{*}{$\begin{array}{l}\text { (I) a4: (Marital } \\
\text { status: ) }\end{array}$} & \multirow{2}{*}{$\begin{array}{l}\text { (J) a3 (Marital } \\
\text { status: ) }\end{array}$} & \multirow{2}{*}{$\begin{array}{l}\text { Mean } \\
(\mathrm{I}-\mathrm{J})\end{array}$} & \multirow[t]{2}{*}{ Difference } & \multirow{2}{*}{$\begin{array}{l}\text { Std. } \\
\text { Error }\end{array}$} & \multirow[t]{2}{*}{ Sig. } & \multicolumn{2}{|c|}{$95 \%$ Confidence Interval } \\
\hline & & & & & & $\begin{array}{l}\text { Lower } \\
\text { Bound }\end{array}$ & $\begin{array}{l}\text { Upper } \\
\text { Bound }\end{array}$ \\
\hline \multirow[t]{3}{*}{ Single } & Married & -.09353 & & .09540 & .761 & -.3397 & .1527 \\
\hline & Divorce & -.01361 & & .14784 & 1.000 & -.3951 & .3679 \\
\hline & Widow/Widower & .45879 & & .24454 & .240 & -.1723 & 1.0899 \\
\hline \multirow[t]{3}{*}{ Divorce } & Single & .09353 & & .09540 & .761 & -.1527 & .3397 \\
\hline & Divorce & .07992 & & .11978 & .909 & -.2292 & .3890 \\
\hline & Widow/Widower & .55232 & & .22867 & .076 & -.0378 & 1.1424 \\
\hline \multirow[t]{3}{*}{ Divorce } & Single & .01361 & & .14784 & 1.000 & -.3679 & .3951 \\
\hline & Married & -.07992 & & .11978 & .909 & -.3890 & .2292 \\
\hline & Widow/Widower & .47240 & & .25504 & .251 & -.1858 & 1.1306 \\
\hline \multirow[t]{3}{*}{ Widow/Widower } & Single & -.45879 & & .24454 & .240 & -1.0899 & .1723 \\
\hline & Married & -.55232 & & .22867 & .076 & -1.1424 & .0378 \\
\hline & Divorce & -.47240 & & .25504 & .251 & -1.1306 & .1858 \\
\hline
\end{tabular}

4.4 Education Level and Leadership Styles

To test if the means of educational level is statistically one way ANOVA test was carried out. The result revealed a sig value .336 which more than .05 .

Table 8. Educational level and leadership styles ANOVA

\begin{tabular}{llllll}
\hline Leadership styles & Sum of squares & Df & Mean square & F & Sig \\
\hline Between Groups & 1.487 & 5 & .297 & 1.146 & .336 \\
Within Groups & 96.50 & 373 & .260 & & \\
Total & 98.337 & 378 & & & \\
\hline
\end{tabular}

\section{Discussion}

The present study successfully replicated, makes several contribution to leadership studies in organizational settings. The overall objective of this research was to find if there is significant difference between social demographic factors and leadership styles in some selected organizations in Malaysia. An independent sample t-test was performed to compare the two groups (Male and female) with regards to their leadership styles. The Levene's test for equality of variances was performed for both variables to test whether the variance of scores for the two groups (male and female) is similar and to test the assumption of equality of variance. The results show that there is no significance difference between the two groups. Therefore we can conclude that differences between the two groups might not be due to gender manipulation when one compares with transformational leadership styles. This result is contrary to other research findings for example Larocca (2003) found significant difference between leadership styles and gender. Related to this finding was the work of Eagly and Johnson (1990) which found that there is difference between gender and leadership where female managers were found to be more democratic than their male counterpart.

To determine if the means for race is statistically different one way ANOVA was carried out to compare the means between the groups. From the ANOVA table since the sig. Value is 0.30 this value is less than 0.5 therefore we conclude that there is a significant difference four groups (Malay, Chinese Indians and others). Further test using the Turkey's Honestly significant Difference test (HSD) was carried out to compare all pairs of group's means and the result are shown in the multiple comparisons table 5. The table showed that there is a significant difference only between Malays and Chinese. However, there was no statistical difference between Indian and Chinese, Malay and Indian, Malay and other races. Therefore the differences that exist between the groups might be due other factors not leadership styles. However it was not surprising from the result of this 
study to find there is no significant difference between educational qualification and leadership styles. Meaning that education levels or certificate does not influence leadership styles of an individual. It is generally believe that transformational leadership is about motivating followers to achieve organizational goals beyond what is originally stated therefore the issues of educational level has little influence on leadership styles.

On top of it, the study also revealed that marital status of an individual is not a determinant of leadership styles. From the study, the four groups (single, married, divorce and widow/widower) are not statistically different between conditions being compared. Therefore we can conclude that the difference between means is likely due to chance and not likely due to marital status manipulation. These results argument those of other researchers, indicating that leadership styles do not necessarily depends on social demographic factors. As argued by Burns (1978) transformational leadership is a process of engendering higher levels of motivation and commitment among followers. The emphasis is on generating a vision for and values of followers and creating a feeling of justice, loyalty and trust. In the organizational sense, transformational leadership is about transforming the performance or fortunes of a business

\section{Conclusion}

In conclusion, the purpose of this study was to determine if there is significance difference between social demographic factors comprising of (gender, marital status, education level and race) and transformational leadership styles. Overall the result of the study indicated that there was no significant difference between social demographic factors and transformational leadership styles which was not the initial aim of the study. However, the current study was able to study these variables as a stepping stone for further research in other organizations. Beside this, the result of this study has explored some of the social demographic characteristic of the top management in Malaysian organizations. Another important finding is demographic imbalance as it relates to gender in top management in these organizations this is something the authorities will further work to reduce the wide gap between male and female in leadership positions.

It will be beneficial if this research is replicated in other organizations outside Malaysia to determine if a social demographic factor varies according transformational leadership style.

\section{References}

Alba, R. (1990). Ethnic identity, The Transformation of white America. New Haven, CT. Yale.

Asgari, A., Silong, A., D., Ahmed, A., \& Abu Samah, B. (2008). The relationship between transformational leadership behaviors, organizational justice, leader-member exchange, perceived organizational support, trust in management and organizational citizenship behaviors. European Journal of Scientific Research, (2), 227-242.

Avolio, B. J. (2005). Leadership development in balance: Made/born. Mahwah, NJ: Lawrence Erlbaum.

Avolio, B. J., \& Bass, M. B. (1995). Individual consideration viewed at multiple levels of Analysis, A multi framework examining the diffusion of transformational leadership. The Leadership Quarterly, 6, 199-218.

Bass, B. M. (1985). Leadership and performance beyond expectations. Free Press.

Beamish, P., W., Karavis, L., Gorzeon, A., \& Lane., C. (1999). The relationship between organizational structure and export performance. MIR: Management International Review, 37-54.

Brown, B. B. (2003). Employees' organizational commitment and their perception of supervisors relations-oriented and task-oriented leadership behaviors. PhD Thesis, Virginia Polytechnic Institute and State University.

Burns, J. M. (1978). Leadership. New York, Harper and Row Publishers.

Eddy, S. W. (2008). Why Organizations choose to manage Diversity? Toward a Leadership- Based Theoretical Framework. Human Resource Development Review, 7(1), 58-78. http://dx.doi.org/10.1177/1534484307311592

Fiedler, F. E. (1967). A theory of leadership Effectiveness. New York, McGraw-Hill.

Gutek, B. A., \& Morasch, B. (1982). Sex ratios, sex role spillover, and sexual harassment of women at work. Journal of Social Issues, 38(4), 55-74. http://dx.doi.org/10.1111/j.1540-4560.1982.tb01910.x

Harrison, D. A., Price, K. H., \& Bell, M. P. (1998). Beyond relational demography: Time and the effects of surface- and deep-level diversity on work group cohesion. Academy of Management Journal, 41(1), 96-107. http://dx.doi.org/10.2307/256901 
Hersey, P., \& Blanchard K. H. (1993). Management of organizational behavior: Utilizing human resources. Prentice-Hall, Inc.

House, R. J., \& Mitchell, T. R. (1974). Path-goal theory of Leadership. Journal of Contemporary Business, 3(4), 81-97.

Jamilah, O., Jeffery, L., \& Kabeer A. M. (2012). Review of Factors that influence Leadership Styles among top Management in Small and Medium size Enterprises. International Business Management, 6, 384-389. http://dx.doi.org/10.3923/ibm.2012.384.389

Judey, M. (2010). Transformational Leadership: A study of Gender differences in Private Universities. Review of Business Research Papers, 4, 118-125.

Krecie, R. V., \& Morgan, D. W. (1970). Determining Sample size for Research Activities. Educational and psychological measurement.

Larocca, M. A. (2003). Perception of leadership qualities in higher education, Impact of professor gender, professor leader style, situation, and participant gender. PhD Thesis, University of South Florida.

Nancy, D., \& Robert, H. (1996). Diversity and the demands of Leadership. Leadership Quaterly, 7(2), 163-187. http://dx.doi.org/10.1016/S1048-9843(96)90039-9

Nunnally, J. (1987). Psychometric Theory. New York: McGraw-Hill.

Ooi, J. B. (1976). Peninsular Malaysia. Longman New York.

Ospina, S., \& Foldy, E. (2009). A critical review of race and ethnicity in the leadership literature: Surfacing context, power and the collective dimensions of leadership. The leadership quarterly, 20(6), 876-896. http://dx.doi.org/10.1016/j.leaqua.2009.09.005

Rowley, C., \& Bhopal., M. (2005). The role of ethnicity in employee relations, The case of Malaysia. Asia Pacific journal of human resources, 43(3), 308-331. http://dx.doi.org/10.1177/1038411105058704

Sarros, J. C., \& Santora, J. C. (2001). The transformational-transactional leadership model in practice. Leadership and Organization Development Journal, 22(8), 383-394. http://dx.doi.org/10.1108/01437730110410107

Stelter, N. Z. (2002). Gender differences in leadership: current social issues and future organizational implications. Journal of Leadership \& Organizational Studies, 8(4), 88-99.

Truckenbrodt, Y. B. (2000). The relationship between leader-member exchange and commitment and organizational citizenship behavior. Acquisition Review Quarterly, 7(3), 233.

Weichun, Z., Ronald, E. R., Bruce, J. A., \& John, J., S. (2011). The Effect of Leadership on follower Moral Identity: Does Transformational/ Transactional Styles make a Difference? Journal of Leadership and organizational Studies, 18(2), 150-160. http://dx.doi.org/10.1177/1548051810396714 